\title{
Manner of Apical Meristem Destruction Affects Growth, Reproduction, and Survival of Sea Oxeye Daisy
}

\author{
Lisa S. Spirko and Anthony M. Rossi \\ Department of Biology, University of North Florida, 1 UNF Drive, Jacksonville, FL 32224, USA \\ Correspondence should be addressed to Anthony M. Rossi; arossi@unf.edu
}

Received 22 May 2015; Accepted 1 September 2015

Academic Editor: Zed Rengel

Copyright ( 2015 L. S. Spirko and A. M. Rossi. This is an open access article distributed under the Creative Commons Attribution License, which permits unrestricted use, distribution, and reproduction in any medium, provided the original work is properly cited.

\begin{abstract}
Although herbivory may result in plant death, the mode and timing of damage may produce variable wounding responses in the attacked plant. In this study, effects of different types of apical meristem damage on growth and performance of sea oxeye daisy Borrichia frutescens (L.) DC were compared. Damage involved either clipping or galling of the apical meristem by the gall midge Asphondylia borrichiae Rossi and Strong. Apical dominance was relatively weak before flowering and stronger in short ramets that were shaded by taller neighbors later in the season. Clipped ramets delayed sprouting new stems, and galled ramets sprouted new stems quickly compared to intact ramets, but final stem counts were similar across treatments. Clipping significantly delayed flowering, reduced seed head ripening time, and resulted in fewer seed heads and seeds. Galling did not significantly impact reproduction compared to intact ramets. Nitrogen supplementation significantly increased stem count and seed count and lengthened seed ripening time. Borrichia frutescens responds differently to clipping versus galling by A. borrichiae and better tolerates galling in terms of nonreproductive performance and survival. Galling from A. borrichiae likely prevents Borrichia frutescens from flowering, which suggests resource regulation of meristems by the midge.
\end{abstract}

\section{Introduction}

Plant-animal interactions such as herbivory and parasitism can vary greatly in their effect on plants, ranging from death and decreased plant performance and fitness at one end of the spectrum $[1,2]$ to resistance (e.g., chemical or physical defenses) and tolerance or compensatory regrowth at the other end [3-12]. Many of these relationships have existed for long periods, and coevolution, or the extent to which species are closely adapted (i.e., coadapted) to each other, has long been understood as the driver by which mechanisms of resistance $[13,14]$ and tolerance $[9,14,15]$ develop.

Tolerance arises from the complex interactions of numerous genetic, physiological, and morphological traits, including plant architecture $[5,8]$, meristem allocation $[7,8,10$, 11, $15]$, nutrient uptake [15], photosynthetic rates $[8,15]$, and phenological timing [3, 15-17], under influence of environmental factors $[10,11,15]$. For example, plant species that hold axillary buds dormant may regain lost tissue if the apical meristem, or actively growing stem tip, is damaged because it disrupts apical dominance, or hormonal suppression of axillary buds by the apical meristem, and allows new growth [3-7, 9-11]. In some cases, overcompensation, or regrowth that exceeds the amount of tissue lost and even results in improved fecundity, has been documented [3,18-21]. The degree of tolerance or compensation is often subject to such environmental factors as the timing of herbivory or parasitism (i.e., the season in relation to the plant's phenological state) and nutrient availability. For instance, Ipomopsis aggregata significantly increased its flowering stems after browsing early in the growing season by ungulates [3]. In another study [16], Gentianella campestris overcompensated in terms of fruits and seeds, but only when simulated herbivory (clipping) occurred during a narrow window in Sweden's growing season. Benner [17] also found overcompensation in transplants of Thlaspi arvense occurred if nutrient supplementation was provided early in the growing season.

Apical meristem damage also may occur as a result of cecidogenesis (gall-making), which involves a unique, intimate relationship between the gall-inducer, typically an 
insect or fungus, and its host plant, and results in a tumor-like overgrowth of plant tissue [22-28]. Gall-inducers tend to be specialists and highly specific to their particular host species, genus, or family and to the organ they attack, suggesting tight coevolutionary relationships in these systems [22, 23, 28, 29]. Gagné [28] reports that gall midges (Cecidomyiidae) are usually monophagous (one host plant species) or oligophagous (a few closely related species). In a review of the literature spanning 196 neotropical species of gall midges, Carneiro et al. [30] found that $92.4 \%$ were monophagous and $5.6 \%$ were oligophagous. Additionally, $90.8 \%$ of the cecidomyiid species reviewed were found to induce galls on only one plant organ (leaves, flowers, or stems), further supporting the claim that they are host specialists. Galling of the apical meristem can disrupt apical dominance and initiate axillary shoots [27, 31, 32]. Thus, since host plants likely coadapted with their associated gall inducers, it is reasonable that plants attacked by apical gall inducers may demonstrate tolerance or compensation in response to the damage.

Galls of the midge Asphondylia borrichiae on the apical meristem of sea oxeye daisy (Borrichia frutescens) are associated with stem bifurcation below the gall [33]. Other types of naturally occurring apical meristem damage, such as chewing by grasshoppers (e.g., Orchelimum fidicinium), are seen rarely in the field (Anthony M. Rossi, personal observation).

The overall goal of this research was to examine the compensatory response of $B$. frutescens to different types of apical meristem damage in young single-stemmed ramets. Damage to the meristem was either sudden (i.e., clipping to simulate chewing) or gradual via galling, which slowly destroyed the apical meristem. Because the plant's ability to compensate depends largely on having a bank of dormant buds in reserve $[3-5,10,11,34]$, the strength of apical dominance in $B$. frutescens was investigated in relation to its response to meristem damage. A second experiment investigated how $B$. frutescens responds to clipping, galling by A. borrichiae, and nutritional differences in terms of growth and reproduction (i.e., flower head and seed production).

\section{Materials and Methods}

2.1. Study System. Borrichia frutescens, commonly known as sea oxeye daisy or bushy seaside tansy, is an herbaceous, halophytic, perennial shrub found in salt marshes along the U.S. Atlantic and Gulf of Mexico coasts [35]. It propagates primarily through extensive rhizomes [36-38] but also produces small, monoecious flower heads consisting of 15-30 petal-like ray florets and 20-75 disc florets per flower head [35-39]. Each floret produces an achene, or dry seed-bearing fruit, and each achene contains a single seed. Peak flowering is between May and July [38], and flowering rates, or the number of flower heads per ramet, range from 3\% to over 20\% (although these rates can be much higher), depending on factors such as season or access to tidal inundations of nutrients [40, 41]. Under greenhouse conditions, seed viability of $90 \%$ was reported by Biber et al. [39].

Borrichia frutescens is the primary host plant of the gall midge Asphondylia borrichiae [33, 41-43]. Adult A. borrichiae are small ( $<3 \mathrm{~mm}$ long), fragile, weak-flying gall midges that live for only 2-3 days, during which their primary activity is breeding [2, 44-46]. Female A. borrichiae collect the conidia of a fungal symbiont and deposit the conidia with her eggs inside the apical meristematic tissue of the host plant during oviposition, which induces a gall to form [42, 45, 47, 48]. Larvae feed on the fungal symbiont, which draws nutrients from plant tissues, and they pupate within the gall $[47,48]$. With occasional exceptions, female midges appear to avoid ovipositing in flower heads [40, 42], and the presence of a gall typically prevents the apical meristems from flowering [33, 42, 45]. Galls persist on the host plant during spring and summer for about seven to ten weeks and senesce after midge eclosion, typically resulting in the death of the galled apical meristem [33, 45]. A previous study at the site in 2005 found moderate correlation between stem count and gall count (Anthony M. Rossi, unpublished data). Aside from galling by A. borrichiae, the sap feeding leafhopper Pissonotus quadripustulatus and the aphid Dactynotus sp. are the only other herbivores regularly associated with $B$. frutescens in Florida [49-51].

2.2. Field Site. This study was conducted at Timucuan Ecological and Historic Preserve in Jacksonville, Florida, USA $\left(\mathrm{N} 30^{\circ} 22^{\prime} 45^{\prime \prime}, \mathrm{W} 81^{\circ} 28^{\prime} 49^{\prime \prime}\right)$. This site features an intertidal back-marsh community bordered by hammock and consisting primarily of Borrichia frutescens. Previous studies at this site $[43,47]$ have found galling on $B$. frutescens to be very high (approximately $30-50 \%$ of apical meristems) and a strong positive correlation between stem number and gall count (Anthony M. Rossi, unpublished data).

2.3. First Bud Break Experiment. To investigate the strength of apical dominance in $B$. frutescens and to test its response to various types of apical meristem damage, 25 single-stemmed $B$. frutescens ramets (i.e., individual plants) were randomly assigned to a stem treatment in May 2013: (1) galled, (2) clipped, or (3) intact. Ramets in the galled group began the experiment with a single stem, but also had a single, live gall (i.e., green, no emergence holes). Clipping was performed by removing the apical meristem and the terminal pair of leaves with scissors (removing approximately $1 \mathrm{~cm}$ of the stem tip). Intact ramets were protected from galling by a mesh bag placed over the apical meristem and secured with a twist tie. Two-way ANOVA on light readings (Basic Quantum Meter, model BQM-SUN, Apogee Instruments Inc., Logan, Utah, USA) taken inside and outside the mesh bags in sunny and shady conditions revealed no effect of the mesh bags or their interaction with light conditions on light penetration (inside versus outside mesh: $F_{1,39}=0.004, P=0.949$; sunny versus shady: $F_{1,39}=3277.478, P<0.001$; mesh $\times$ light: $F_{1,39}=$ $0.022, P=0.882)$. Ramets were monitored for bud break biweekly and, after eight weeks, the node number bearing the bud to break first was recorded ( $0=$ apical meristem or clipped stem tip, 1 = first node below apical meristem, etc.) and its distance measured from the apical meristem or clipped stem tip (nearest $0.1 \mathrm{~cm}$ ). Differences in the number of surviving ramets that broke bud at eight weeks were 
tested using a $\chi^{2}$ test. One-way ANOVA was used to test the number of days and distance to first bud break. Variances of time data were homogeneous, but due to small sample sizes of surviving ramets, normality was inferred based on a linear probability plot of residuals. Distance data were squareroot transformed to achieve normality and homogeneity of variances. After a significant main effect, group means were analyzed with Tukey's HSD test to examine planned pairwise comparisons between treatments. The ratio of ramets with different frequencies of nodes bearing bud break was tested using $\chi^{2}$ test. Due to low sample sizes, frequencies for nodes two and more distal from the apical meristem were pooled, and the $\chi^{2}$ test compared nodes 0,1 , and $2+$ across treatments.

2.4. Stem Condition and Nutritional Status Experiment. To test the effects of apical meristem damage on regrowth, seed set, quality, and viability and any interaction with plant nutritional status (i.e., nitrogen levels), a $3 \times 2$ fully factorial experiment involving three stem treatments (galled, clipped, and intact) and two nutrient treatments (fertilized and not fertilized) was initiated in January, about 11 weeks before the flowering season started. For this experiment, approximately 300 single-stemmed Borrichia frutescens were selected haphazardly and assigned randomly to one of six groups: (1) galled and fertilized; (2) galled and not fertilized; (3) clipped and fertilized; (4) clipped and not fertilized; (5) stem intact and fertilized; and (6) stem intact and not fertilized (control). Each of the previous treatments began the experiment with 50 ramets (i.e., individual plants). Ramets in the galled groups began the experiment with a single stem and gall. Clipped ramets were clipped once at the beginning of the experiment. Intact ramets were left unprotected from galling. However, many intact ramets were expected to be galled during the experiment $[43,47]$ and may have severely reduced the sample size of the control group. Therefore, in addition to the first control group of 50 ramets, a second control group of 20 additional intact, unfertilized ramets was selected haphazardly and protected from galling by a mesh bag. After experiment completion, all statistical analyses were first conducted on the bagged and unbagged control groups only and, finding no significant differences between them, data were pooled into a single control group for all remaining analyses.

Ramets in the three fertilized treatment groups received a small amount (ca. $2 \mathrm{~g}$ ) of supplemental nitrogen in the form of blood meal (N-P-K: 12-0-0; Miracle-Gro Organic Choice Blood Meal, Scotts Miracle-Gro Products, Marysville, Ohio, USA) every four weeks. The blood meal was applied by carefully forming a hole approximately $3-4 \mathrm{~cm}$ deep, or as allowed by the soil compacted with oyster shells, near the base of the ramet using a screwdriver, pouring the blood meal into the hole, and covering it with substrate. Effects of the hole were controlled in the nonfertilized groups by creating a hole and then filling it in.

Total stem counts (i.e., main stem and axillary stems) and the presence of flower head buds on ramets were assessed every two weeks from January through June 2013. Stems were counted if they were alive and at least one centimeter long. Flower head buds were tagged at first appearance through the end of June and were monitored biweekly until seed head harvesting, which concluded in early September, with the initiation date of each phenological event (i.e., budding, blooming, and ripening) and harvesting recorded. After each flower head finished blooming (i.e., all florets had senesced and/or abscised), a mesh bag was placed over them and seed heads were harvested when they were brown and dry and the stalk was senescent. Each seed head was carefully broken apart and each "seed" (achene, or dry seed-bearing fruit) separated from its bract with forceps. Seeds that were abnormally developed (shriveled, malformed) were removed. Normal seeds were counted and weighed to the nearest $10^{-4} \mathrm{mg}$.

Germination success of the normally developed seeds produced was determined in September after all seed heads had been harvested and processed; abnormally developed seeds were excluded from the germination phase of the experiment. Twenty-five seeds or fewer, if less than 25 seeds developed, were randomly selected from each seed head and soaked for 48-60 hours in tap water [39]. All seeds for each seed head were planted together in the cell of a horticultural flat or a seedling pot in a 1:1 blend of Ace Horticultural Grade Vermiculite (A. H. Hoffman, Inc., Landisville, Pennsylvania, USA) and Organic Seed Starting JiffyMix (Ferry-Morse Seed Company, Fulton, Kentucky, USA), the latter which contained $48-52 \%$ sphagnum peat moss, $48-52 \%$ vermiculite, lime, and an organic wetting agent. No fertilizers were included in the original manufactured products or added to the final planting mixture. Seeds were very lightly covered with planting medium, placed in light shade in a greenhouse $\left(\approx 25-30^{\circ} \mathrm{C}, \approx 60 \%\right.$ relative humidity), and lightly watered under timed misters for four minutes every four hours for 12 weeks. Because unequal numbers of seed heads were produced in each treatment, a Latin square layout was not possible. Treatments were randomized across rows and columns as possible.

Except where noted, all statistical analyses were conducted on ramets surviving to the end of the experiment and on intact ramets remaining intact (ungalled) until the end of the experiment. Mean $( \pm \mathrm{SD})$ overall survivorship across all treatments at the end of the experiment was $76.6 \pm 0.9 \%$ and ranged from a low of $74.2 \%$ for clipped ramets to a high of $78.8 \%$ for intact ramets. These differences were not significantly different across treatments (stem: $\chi^{2}=0.629, d f=$ 2, and $P=0.730$; fertilizer: $\chi^{2}=0.357, d f=1$, and $P=0.550$ ); therefore statistical analyses of counts could be performed with the assumption that the number of surviving ramets was similar across treatments. Stem counts at the end of the experiment were found to follow a Poisson distribution because ramets began the experiment with a single stem and the experiment was conducted over a relatively short period of time ( 25 weeks). Thus, stem counts were not parametric and were tested across stem treatments and fertilization treatments using Kruskal-Wallis tests. Chi-square $\left(\chi^{2}\right)$ tests were used to test the number of ramets that produced flower head buds and the total number of seed heads produced across treatments. The number of days to first flowering, or the number of days between the start of the experiment and the day the first flower head bud on each flowering 


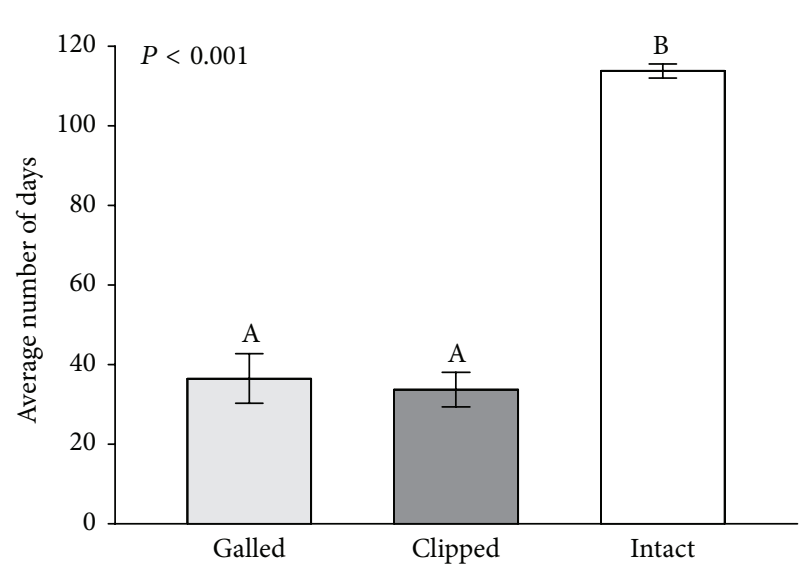

(a)

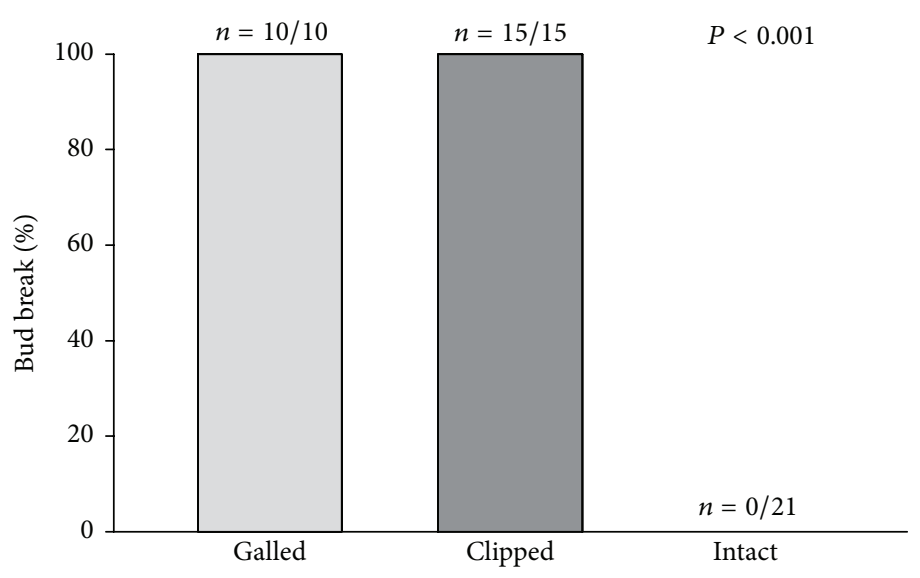

(b)

FIGURE 1: In the first bud break experiment, (a) average number of days to first bud break with SEM error bars across stem treatments $\left(F_{2,24}=45.568, P<0.001\right)$ and (b) percent bud break occurring by eight weeks across stem treatments $\left(\chi^{2}=46.000, d f=2\right.$, and $\left.P<0.001\right)$. Different letters in (a) indicate significant differences among treatments (Tukey's post hoc with Bonferroni correction to $\alpha=0.017$ ).

ramet was recorded, was tested across stem treatments and fertilization treatments using Kruskal-Wallis tests. KruskalWallis was used in this instance because assumptions of ANOVA could not be met for some groups and data (and associated residuals) could not be transformed to achieve normality and homogeneity of variances for all groups. Initial height was statistically different among the stem treatments; galled ramets (mean \pm SE: $33.0 \pm 1.9 \mathrm{~cm}$ ) were between 41 and $50 \%$ taller than clipped $(23.4 \pm 2.6 \mathrm{~cm})$ and intact ramets $(22.0 \pm 1.7 \mathrm{~cm})$, respectively (Kruskal-Wallis: $\chi^{2}=$ 23.794, $d f=2$, and $P<0.001)$. This difference is likely because apical meristems above the canopy are more likely to be visible to ovipositing females; thus, two-way analysis of covariance (ANCOVA) was used on seed count, seed mass, and the number of days budding, blooming, and ripening (phenological timing) with initial height as the covariate. ANCOVA included bootstrapping (1,000 bootstrap samples) to improve confidence limits due to small sample size for some groups. For phenological timing, although variances were homogeneous, sample sizes for flowering ramets in the clipped group were small ( $n=7)$; thus, these results should be viewed with caution. Seed germination rates were tested using chi-square $\left(\chi^{2}\right)$ tests. Significant ANCOVA results were analyzed using contrasts with automatic Sidak correction. Significant ANOVA results among stem treatments were analyzed using Tukey's HSD tests. Significant Kruskal-Wallis results among stem treatments were analyzed using MannWhitney $U$ with Bonferroni correction $(\alpha=0.017)$. All statistical tests were conducted using PASW Statistics (currently known as SPSS Statistics), version 18.0.0 (IBM, Armonk, NY).

\section{Results}

3.1. First Bud Break Experiment. Stem treatment had a highly significant effect on the number of days to first bud break $\left(F_{2,24}=45.568, P<0.001\right)$. Both galled and clipped surviving ramets broke bud within the first 40 days (mean \pm SE:
$36.4 \pm 6.3$ and $33.6 \pm 4.3$, resp.) and were statistically similar, while intact surviving ramets were significantly slower and broke bud about 80 days later (113.8 \pm 1.8 ) (Figure 1(a)). Stem treatment also had a highly significant effect on the number of surviving ramets that broke bud by eight weeks $\left(\chi^{2}=\right.$ 46.000, $d f=2$, and $P<0.001$ ) (Figure $1(\mathrm{~b})$ ). Slightly more clipped ramets than galled ramets broke bud in the first five weeks. By eight weeks, 100\% of surviving galled and clipped ramets had broken bud, while no intact ramets had broken bud by this time. Intact ramets did not begin to break bud until sixteen weeks.

Stem treatment had a highly significant effect on the distance $(\mathrm{cm})$ from the stem terminal to the first bud break $\left(F_{2,24}=12.474, P<0.001\right)$. Clipped ramets broke bud significantly closer to the terminal, with an average distance of $1.3 \pm 0.2 \mathrm{~cm}$ from the terminal, compared to intact ramets, which broke bud an average distance of $6.6 \pm 2.0 \mathrm{~cm}$ (Figure 2(a)). Galled ramets broke bud an average distance of $3.0 \pm 0.7 \mathrm{~cm}$ from the terminal and were statistically similar to both the clipped and intact groups. Stem treatment also had a highly significant effect on the node bearing first bud break $\left(\chi^{2}=14.534, d f=4\right.$, and $\left.P=0.006\right)$ as counted from the stem terminal (node 0) (Figure 2(b)). Clipped ramets first broke bud at an average node of $0.8 \pm 0.2$. Approximately $25 \%$ of clipped ramets broke bud directly at the stem terminal and were the only group to do so. Galled ramets broke bud at an average node of $1.9 \pm 0.3$, with most bud breaks occurring at node 1 and the remaining breaks being split evenly between nodes 2 and 3 . Intact ramets broke bud at an average node of $4.5 \pm 1.2$, and never broke bud closer to the terminal than node 3 . One ramet broke bud first at node 8 .

3.2. Stem Condition and Nutritional Status Experiment. Stem treatment had no effect on the total number of stems at the end of the experiment (week 25) $\left(\chi^{2}=0.986, d f=2\right.$, and $P=0.611)$ with galled ramets having an average of $4.1 \pm 0.6$ (SE) stems, compared to $4.1 \pm 0.5$ stems for clipped 

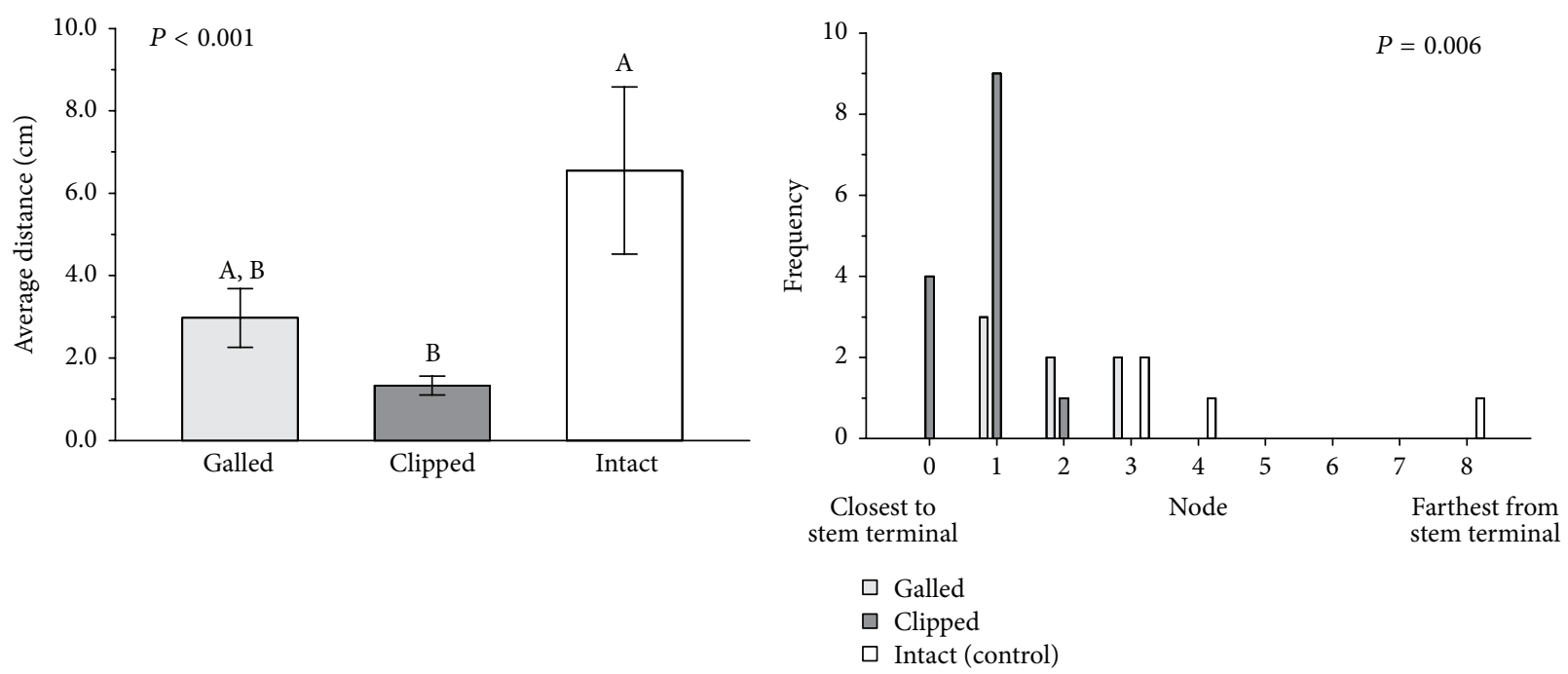

(a)

(b)

FiguRE 2: In first bud break experiment, (a) average distance to first bud break in centimeters, as measured from the stem terminal to the node bearing the first lateral meristem to break bud, with SEM error bars $\left(F_{2,24}=12.474, P<0.001\right)$ and $(b)$ frequencies of first bud breaks occurring at different nodes $(0=$ stem terminal, $1=$ first node below terminal, etc. $)\left(\chi^{2}=14.534, d f=4\right.$, and $\left.P=0.006\right)$. In $(a)$, data were square-root transformed to meet ANOVA assumptions but are presented untransformed for clarity. Different letters indicate significant differences among treatments (Tukey's post hoc with Bonferroni correction to $\alpha=0.017$ ).

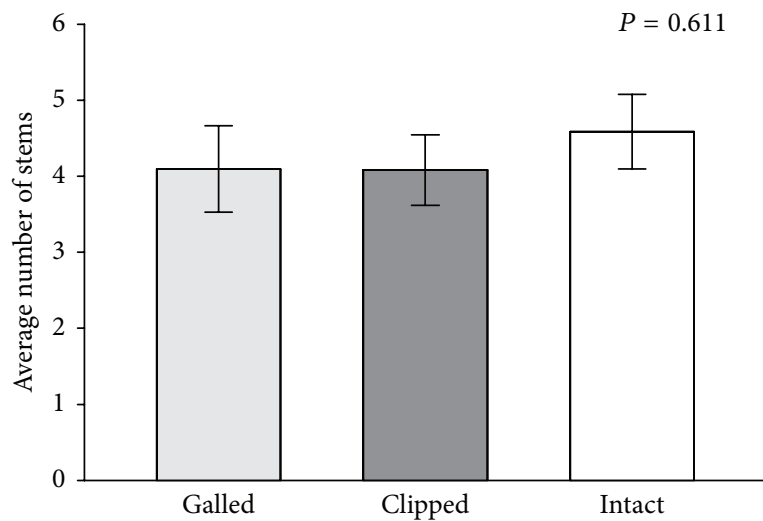

(a)

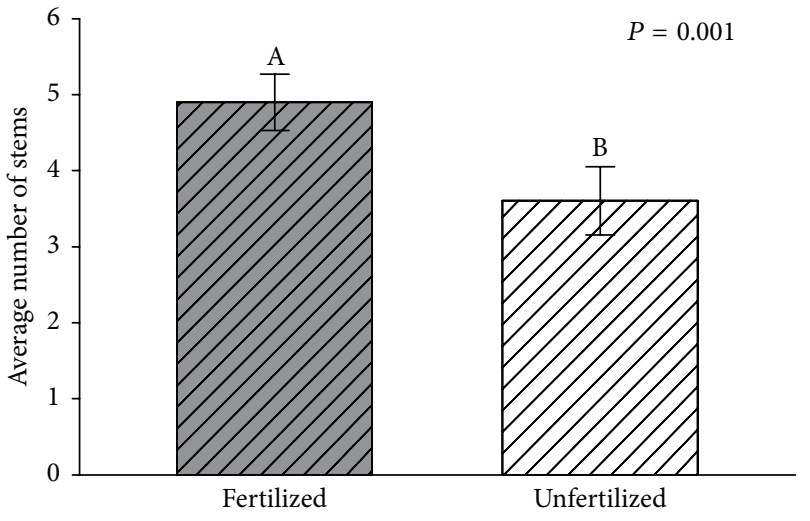

(b)

FIGURE 3: In stem-nutrition experiment, average number of stems at week 25 with SEM error bars across (a) stem treatments $\left(\chi^{2}=\right.$ 0.986, $d f=2$, and $P=0.611)$ and (b) fertilization treatments $\left(\chi^{2}=11.973, d f=1\right.$, and $\left.P=0.001\right)$. Different letters indicate significant differences among treatments.

ramets and $4.6 \pm 0.5$ stems for intact ramets (Figure 3(a)). Galled ramets had dramatic increases in stem count within the first month, while clipped ramets appeared to be delayed in sprouting new stems. Stem count increased modestly in intact ramets until week 15 , after which average stem count in that group was comparable to that in galled and clipped plants. Approximately $27 \%$ of intact/unfertilized (control) ramets broke bud by week 3 and $44 \%$ by week 11, when flower buds began to appear on the ramets. Fertilization treatment had a highly significant effect on the number of stems at the end of the experiment $\left(\chi^{2}=11.973, d f=1\right.$, and $\left.P=0.001\right)$ with fertilized ramets having an average maximum of $4.9 \pm 0.4$ stems, compared to $3.6 \pm 0.5$ stems for unfertilized ramets (Figure 3(b)).
Stem treatment had a highly significant effect on the average number of days before first flowering occurred in flowering ramets $\left(\chi^{2}=19.747, d f=2\right.$, and $\left.P<0.001\right)$ with clipped ramets flowering significantly later than either galled and intact ramets (Figure 4(a)). With Bonferroni correction $(\alpha=0.017)$, galled and intact ramets were not significantly different. Clipped ramets flowered at an average of $136.2 \pm 4.7$ days after the beginning of the experiment, three weeks later than galled ramets (115.9 \pm 3.2 days) and a full month later than intact ramets $(106.2 \pm 2.8$ days $)$. Fertilization treatment had no effect on the number of days to first flowering $\left(\chi^{2}=\right.$ 1.323 , $d f=1$, and $P=0.250$ ), with fertilized ramets flowering an average of about five days earlier (111.6 \pm 2.8 days) than unfertilized ramets (116.6 \pm 4.0 days) (Figure $4(\mathrm{~b})$ ). 


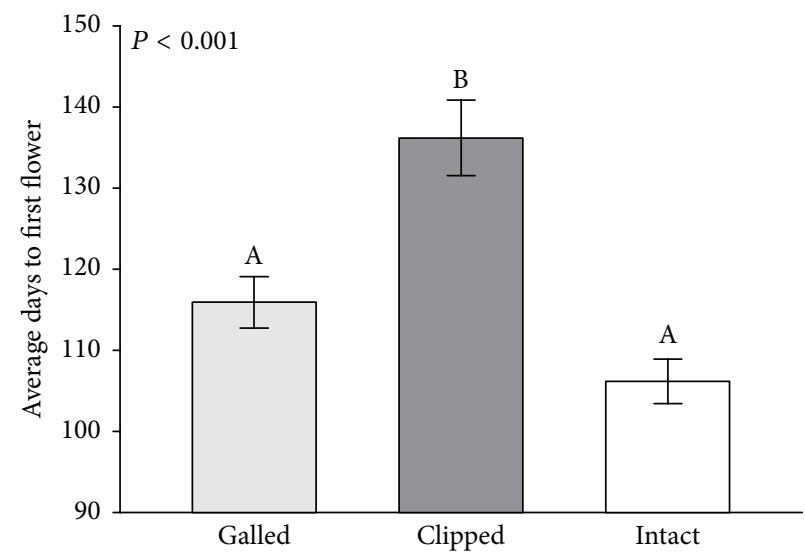

(a)

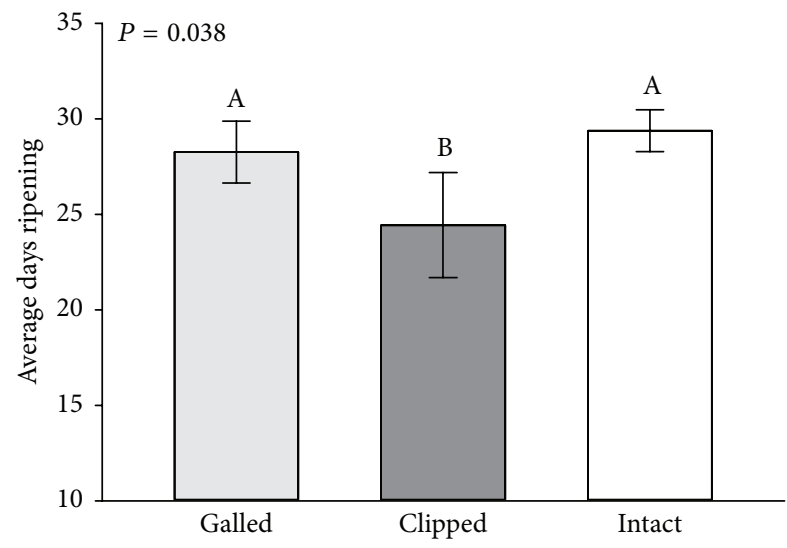

(c)

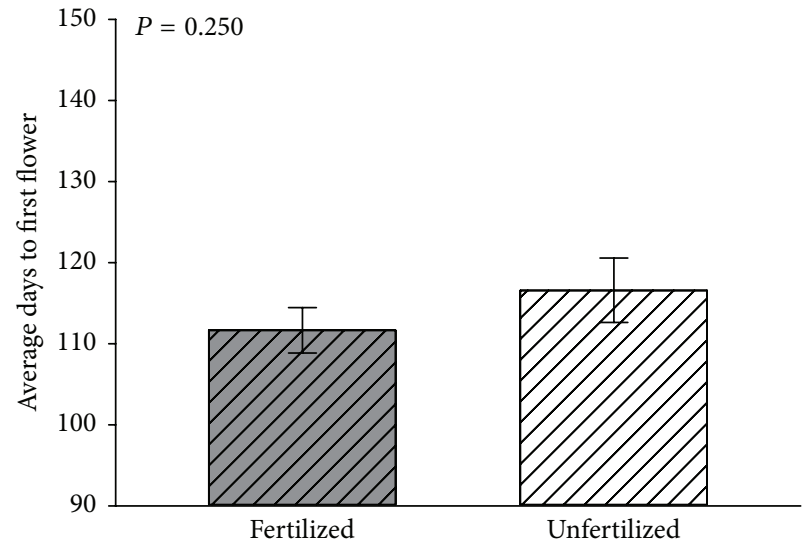

(b)

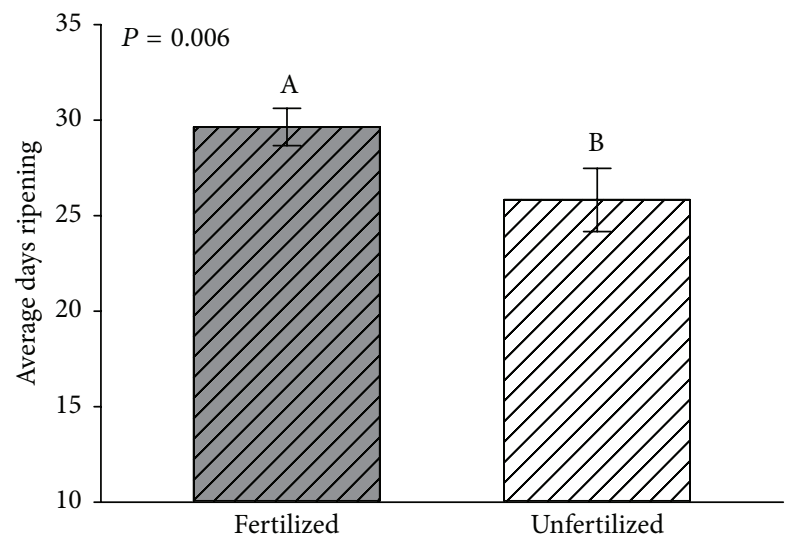

(d)

FIGURE 4: In stem-nutrition experiment, average number of days until appearance of first flower bud in flowering ramets only with SEM error bars across (a) stem treatments $\left(\chi^{2}=19.747, d f=2\right.$, and $\left.P<0.001\right)$ and (b) fertilization treatments $\left(\chi^{2}=1.323\right.$, $d f=1$, and $P=0.250)$ and average number of days seed heads ripened with SEM error bars across (c) stem treatments and (d) fertilization treatments (stem treatment: $F_{2,47}=3.566, P=0.038$; fertilization treatment: $F_{1,47}=8.281, P=0.006$; stem $\times$ fertilization: $F_{2,47}=1.401, P=0.258$; covariate: $F_{1,47}=0.013, P=0.911$ ). Different letters indicate significant differences among treatments (Mann-Whitney for Kruskal-Wallis and Tukey's for ANCOVA for stem treatments with Bonferroni correction to $\alpha=0.017$ ).

Stem treatment had no effect on the number of days in flower bud stage $\left(F_{2,46}=0.298, P=0.744\right)$ with flower heads on galled ramets spending an average of $24.5 \pm 2.0$ days as flower buds, clipped ramets an average of $22.0 \pm 2.8$ days, and intact ramets an average of $23.5 \pm 1.4$ days. Fertilization treatment also had no effect on the length of flower bud stage $\left(F_{1,46}=0.004, P=0.950\right)$ with flower heads on fertilized ramets spending an average of $23.6 \pm 1.4$ days as flower buds and on unfertilized ramets an average of $23.7 \pm 1.7$ days. No significant interaction between stem and fertilization treatments was revealed $\left(F_{2,46}=0.057, P=0.945\right)$. The covariate, initial height, also had no significant influence on the length of flower bud stage $\left(F_{1,46}=0.004, P=0.949\right)$.

Stem treatment had no effect on the number of days in the blooming stage $\left(F_{2,46}=1.859, P=0.169\right)$ with flower heads on galled ramets blooming for an average of $25.5 \pm 1.4$ days, on clipped ramets for an average of $21.3 \pm 2.7$ days, and on intact ramets for an average of $26.5 \pm 1.5$ days. Fertilization treatment also had no effect on the length of blooming stage $\left(F_{1,46}=\right.$ 0.848, $P=0.363$ ) with flower heads on fertilized ramets blooming for an average of $25.8 \pm 1.3$ days and on unfertilized ramets for an average of $24.6 \pm 1.5$ days. No significant interaction between stem and fertilization treatments was revealed $\left(F_{2,46}=0.267, P=0.767\right)$. Again, the covariate, initial height, also had no significant influence on blooming time $\left(F_{1,46}=0.261, P=0.612\right)$.

However, stem treatment had a significant effect on the number of days seed heads spent ripening $\left(F_{2,47}=\right.$ 3.566, $P=0.038$ ) with those on clipped ramets ripening significantly earlier than those on galled and intact ramets, which were statistically similar to each other (Figure 4(c)). Planned contrasts indicated that clipping had a significantly negative effect on ripening time compared to the galled group $(P=0.006,95 \%$ CI $[1.800,10.291])$ and the intact group $(P=0.011,95 \%$ CI $[-12.616,-1.719])$. Again, the galled group was intermediate between the control and clipped groups, but it was not significantly different from the intact group $(P=0.419,95 \%$ CI $[-6.035,2.563])$. Seed heads on clipped ramets ripened for an average of $24.4 \pm 2.8$ days, or about $4-5$ fewer days than galled ( $28.3 \pm 1.6$ days) and intact 


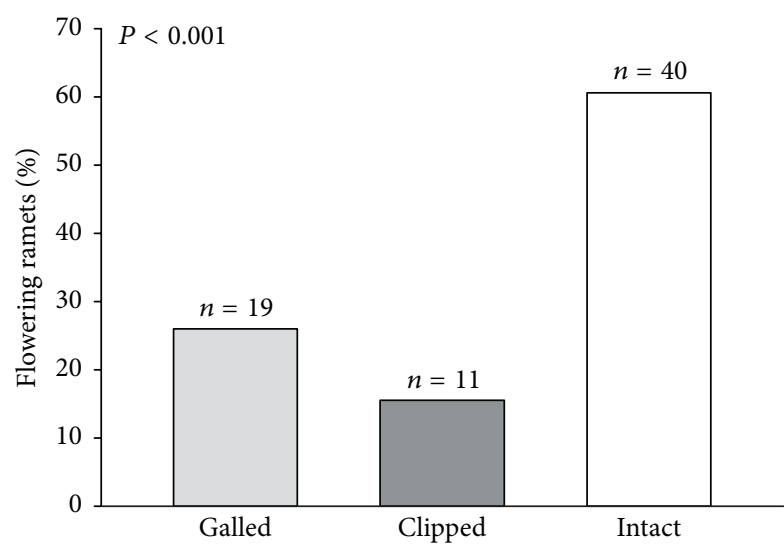

(a)

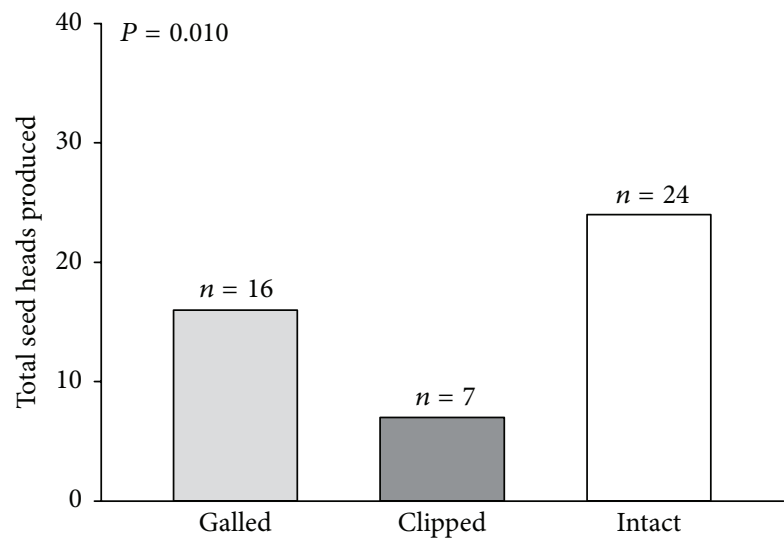

(c)

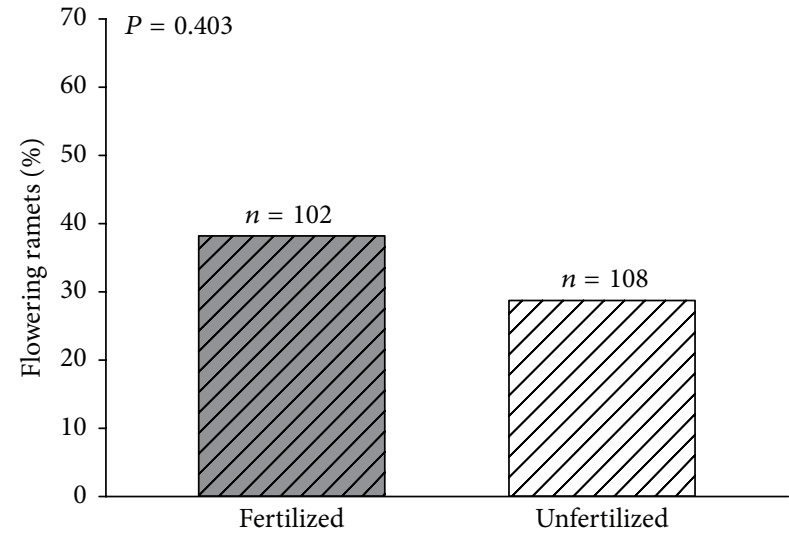

(b)

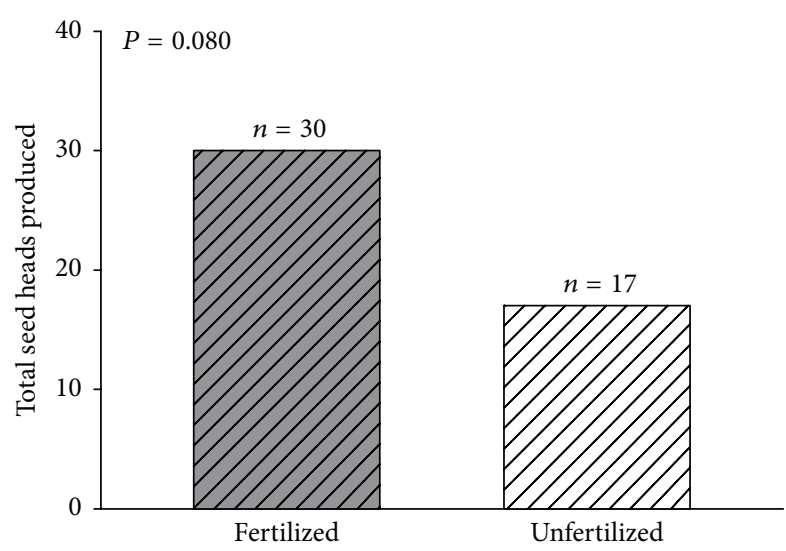

(d)

FIGURE 5: In stem-nutrition experiment, total number of ramets producing flower buds across (a) stem treatments $\left(\chi^{2}=19.229, d f=2\right.$, and $P<0.001)$ and (b) fertilization treatments $\left(\chi^{2}=0.700, d f=1\right.$, and $\left.P=0.403\right)$ and total number of seed heads produced across (c) stem treatments $\left(\chi^{2}=9.234, d f=2\right.$, and $\left.P=0.010\right)$ and $(\mathrm{d})$ fertilization treatments $\left(\chi^{2}=3.064, d f=1\right.$, and $\left.P=0.080\right)$.

ramets $(29.4 \pm 1.1$ days). Fertilization treatment also had a highly significant effect on the length of the ripening stage $\left(F_{1,47}=8.281, P=0.006\right)$ with seed heads on fertilized ramets ripening for an average of $29.6 \pm 1.0$ days, or nearly four days longer than unfertilized ramets $(25.8 \pm 1.7$ days $)$ (Figure 4(d)). No significant interaction between stem and fertilization treatments was revealed $\left(F_{2,47}=1.401, P=\right.$ $0.258)$. The covariate, initial height, also had no significant influence on ripening time $\left(F_{1,47}=0.013, P=0.911\right)$.

Stem treatment had a highly significant effect on the number of ramets producing flower buds $\left(\chi^{2}=19.229, d f=\right.$ 2 , and $P<0.001)$, with intact ramets producing twice as many total flower buds (40) as galled ramets (19) and nearly four times as many flower buds as clipped ramets (11) (Figure 5(a)). Fertilization treatment had no effect on the number of ramets producing flower buds $\left(\chi^{2}=0.700, d f=\right.$ 1 , and $P=0.403$ ), with fertilized ramets producing 39 flower buds and unfertilized ramets producing 31 flower buds (Figure 5(b)). Stem treatment also had a highly significant effect on the total number of seed heads produced $\left(\chi^{2}=\right.$ 9.234, $d f=2$, and $P=0.010$ ) with intact ramets producing a total of 24 seed heads compared to 16 for galled ramets and 7 for clipped ramets (Figure 5(c)). Although suggestive, fertilization treatment had no effect on the number of seed heads produced $\left(\chi^{2}=3.064\right.$, $d f=1$, and $P=0.080$ ) with fertilized ramets producing 30 seed heads and unfertilized ramets producing 17 seed heads (Figure $5(\mathrm{~d})$ ).

Both stem treatment and fertilization treatment had highly significant effects on normal versus abnormal seed development (stem: $\chi^{2}=13.499, d f=2$, and $P<0.01$; fertilization: $\chi^{2}=60.314, d f=1$, and $\left.P<0.001\right)$. Stem treatment also had a significant effect on the average number of apparently normally developed seeds per seed head $\left(F_{2,47}=\right.$ 4.370, $P=0.019$ ) (Figure 6(a)). Planned contrasts indicated that clipping had a significantly negative effect on seed count compared to the galled group $(P=0.020,95 \%$ CI [6.039, $66.450])$ and the intact group $(P=0.005,95 \%$ CI $[-95.368$, $-17.834])$. The galled group was not significantly different from the intact group $(P=0.005,95 \%$ CI $[-95.368,-17.834])$ but was lower, as expected. Average seed count per seed head was significantly lower for clipped ramets at $58.1 \pm 14.0$ per seed head, compared to $83.9 \pm 11.4$ seeds per head for galled ramets and $100.7 \pm 8.6$ seeds per head for intact ramets. Fertilization treatment also had a significant effect on seed 


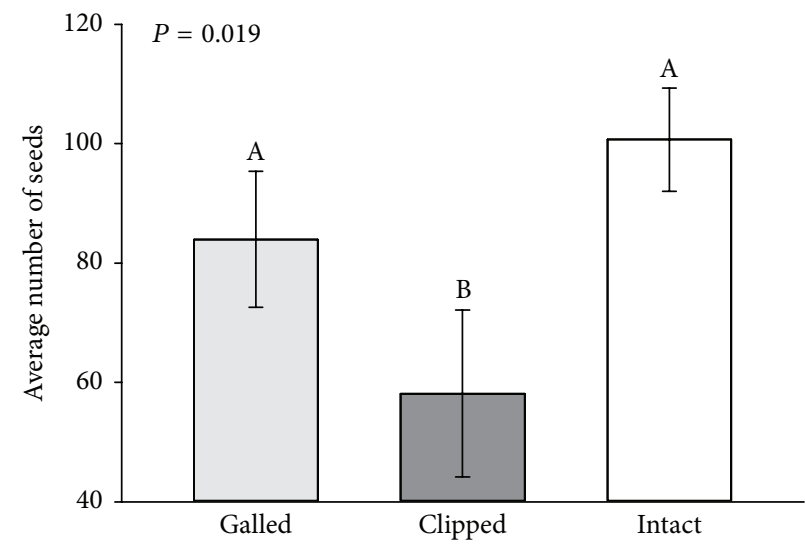

(a)

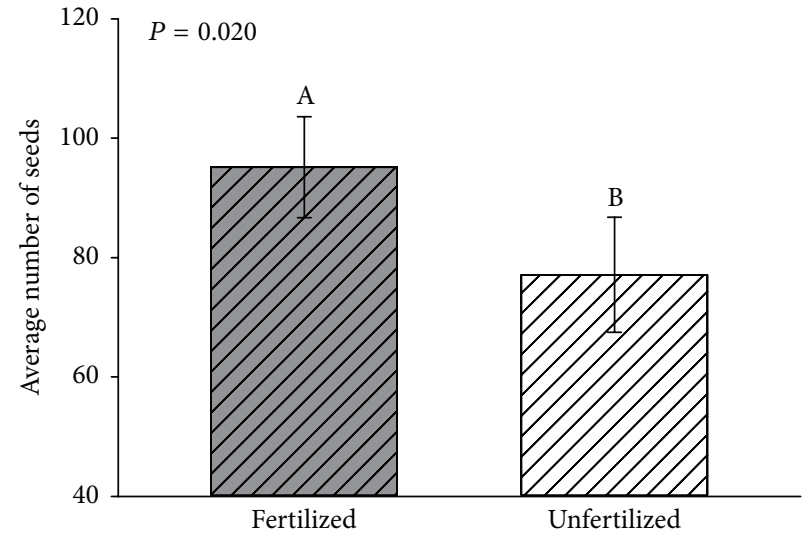

(b)

FIgure 6: Average seed count per seed head with SEM error bars across (a) stem treatments and (b) fertilization treatments in the stemnutrition experiment (stem treatment: $F_{2,47}=4.370, P=0.019$; fertilization treatment: $F_{1,47}=5.881, P=0.020$; stem $\times$ fertilization: $F_{2,47}=1.223, P=0.305$; covariate: $\left.F_{1,47}=2.941, P=0.094\right)$. Different letters indicate significant differences among treatments (Tukey's with Bonferroni correction to $\alpha=0.017$ for stem treatments).

count $\left(F_{1,47}=5.881, P=0.020\right)$ with average seed count per seed head being significantly higher in fertilized ramets $(95.2 \pm 8.5)$ compared to unfertilized ramets $(77.1 \pm 9.6)$ (Figure 6(b)). No significant interaction between stem and fertilization treatments was revealed $\left(F_{2,47}=1.223, P=\right.$ $0.305)$. The covariate, initial height, also had no significant influence on seed count $\left(F_{1,47}=2.941, P=0.094\right)$.

Stem treatment had no effect on seed mass of normally developed seeds $\left(F_{2,47}=0.856, P=0.433\right)$ with average mass per seed being $0.9 \pm 0.1 \mathrm{mg}$ for galled ramets, compared to $0.8 \pm 0.1 \mathrm{mg}$ for clipped ramets and $0.8 \pm 0.0 \mathrm{mg}$ for intact ramets. Although fertilization produced slightly larger seeds, the effect on seed mass was not significant $\left(F_{1,47}=\right.$ $0.362, P=0.551)$ with average mass per seed being $0.9 \pm$ $0.0 \mathrm{mg}$ for fertilized ramets, compared to $0.8 \pm 0.1 \mathrm{mg}$ for unfertilized ramets. No significant interaction between stem and fertilization treatments was found $\left(F_{2,47}=0.060, P=\right.$ $0.942)$. The covariate, initial height, also had no significant influence on seed mass $\left(F_{1,47}=1.595, P=0.214\right)$. Seed germinations were low across all treatments, with only $9.2 \%$ of all sowed seeds germinating. Stem treatment had no effect on germination $\left(\chi^{2}=1.582, d f=2\right.$, and $\left.P=0.453\right)$ with $9 \%$ germination success in the galled group, compared to $7 \%$ in the clipped group and $10 \%$ in the intact group. Curiously, fertilization treatment had a highly significant effect on seed germination success $\left(\chi^{2}=8.418, d f=1\right.$, and $P=$ 0.004 ) with $7 \%$ germination success in the fertilized group, compared to $13 \%$ in the unfertilized group.

\section{Discussion}

The first bud break experiment investigated the strength of apical dominance and the effects on different types of stem damage on it. The distance at which intact ramets broke bud and the extended amount of time it took for them to break bud suggest that apical dominance is strong in Borrichia frutescens. However, stem count at the end of the stem-nutrition experiment ( 25 weeks) was similar across all treatment groups, and at least some ramets in all treatments broke bud shortly after the experiment began. This apparent contradiction is likely due to differences in the strength of apical dominance at different times of the season; the stemnutrition experiment was started in January, before flowering, while the first bud break experiment was started in May, after flowering began. Changes in photoperiod in spring [52-54] and flowering $[4,55]$ are both known to trigger a weakening in apical dominance in some plant species, possibly to maximize the number of meristems available for flower head production. Additionally, foliage in January was sparse and became denser by May, at which point singlestemmed (i.e., young) B. frutescens used in the bud break experiment were notably shorter and more shaded than their neighbors. Light competition has been known to strengthen apical dominance and reduce branching $[4,53,56]$. The finding that apical dominance in intact ramets weakens before flowering is important because overcompensation can occur only when apical dominance is strong and the plant has a bank of dormant buds in reserve for recovery after damage $[3-5,10,11,34]$. In order for reproductive benefits to be realized, strong apical dominance must be maintained before and during flowering so that its disruption leads to significantly more flower heads and seeds compared to intact ramets. Clearly, that was not the case in this study.

Borrichia frutescens is a long-lived perennial and even under nonstressful conditions (e.g., readily available water, soil nutrients, etc.), damage may extend phenological stages (e.g., growth, flowering, etc.). For instance, if the flowering stage is delayed, it may affect the fitness of the plant by altering pollination opportunities [57]. In the stem-nutrition experiment, clipping was detrimental to reproduction in terms of significant delays in flowering and shorter seed head ripening times. Delays in flowering suggest that florets on clipped ramets may have missed the window of opportunity for cross-pollinating with other florets in the population, 
while shortened ripening time may have resulted in poor seed development. Such phenological abnormalities can be expected to affect seed production, and indeed, clipped ramets produced significantly fewer seed heads and normally developed seeds per seed head.

Clipping may have been detrimental because removing the apical meristem also involved removing the terminal pair of leaves associated with it. Since single-stemmed ramets were sparsely foliated in January, removing even a single pair of leaves may have drastically reduced the plants' photosynthetic area and caused a carbon limitation. Such a limitation may delay regrowth, which was evidenced by the one-month lag in stem count in clipped ramets. Since regrowth can redirect nutrients away from reproduction when it precedes flowering in the population $[3,16,58]$, the subsequent onemonth delay in flowering in clipped ramets is not surprising. Additionally, naturally occurring apical meristem damage similar to clipping, such as chewing by grasshoppers (e.g., Orchelimum fidicinium), is seen rarely in the field (Anthony M. Rossi, personal observation), suggesting that this type of damage probably does not exert strong selective pressure and that $B$. frutescens is poorly adapted to it. A high risk of chewing would need to exist for a beneficial or neutral response to it to be adaptive $[16,19,52]$.

Both clipping and galling had detrimental effects on $B$. frutescens, but galling had less impact. Borrichia frutescens has had a long-term association with galling by Asphondylia borrichiae [43], which may have exerted strong selective pressure over time to which $B$. frutescens is better adapted and not overly burdened. Indeed, galled ramets were slightly, but not significantly, different from intact ramets for several of the performance variables assessed in the current study. However, galled ramets produced $50 \%$ fewer flower buds than intact ramets, suggesting that galling may present a form of resource regulation, which has been identified in other galling systems $[31,32]$. Meristems damaged by cecidogenesis or other types of herbivory are essentially removed from the pool of meristems available for the plant's growth and reproduction $[5,7,8,10,11]$. Additionally, although leaves at the galled terminal as well as the gall itself can remain green for some time, galls can significantly redirect nutrients from plant functions to feed the gall-inducing organism $[5,22,23$, 26,59 ], making any photosynthesis by those tissues likely beneficial only to the gall-inducer and not the plant itself. Thus, the reallocation of meristems and nutrients from plant growth and reproduction to A. borrichiae gall development may ensure a steady supply of available (nonflowering) meristems for future generations of gall midges by maintaining apical meristems of $B$. frutescens in a nonflowering state.

Borrichia frutescens occurs primarily in saline habitats and, as Fernandes and Ribeiro [57] point out, stress and nutrient availability are likely to affect a plant's ability to recover from damage. The fate of regrown shoots (e.g., survival, growth rate, and galling rate) was not assessed in the current study, but they may have performed poorly compared to undamaged primary shoots. However, being a tidal environment, water is not likely to be limiting. Additionally, only three variables increased significantly under nitrogen supplementation: final stem count, number of days for seed head ripening, and the number of normal seeds per seed head. These results suggest that nitrogen also is probably not a limiting nutrient at this site, and the small amount used in this experiment may have been insignificant compared to the twice-daily tidal influx of nutrients. A previous fertilization study reported vigorous regrowth and other beneficial responses of Borrichia frutescens, but that study utilized relatively high concentrations of highly soluble inorganic ammonium nitrate [40]. Thus, stem number and seed count may be phenotypically plastic characteristics that respond more readily to changes in nutrient level and other environmental conditions compared to the other response variables tested in this experiment. Indeed, previous studies suggest that nutrient supplementation via roots may override apical dominance when it is weak and result in the growth of new stems $[4,11,54,55]$. Nutrient supplementation can also increase the production of normally developed seeds by allowing plants to allocate more nutrients to reproduction [58]. An increase in the number of days for seed head ripening may also enhance seed development and decrease the chances of seed abortion by allowing fertilized ova more time to acquire adequate nutrient and energy stores. Finally, while the count of normally developed seeds varied significantly across both stem treatments and fertilizer treatments in this experiment, seed mass, an important measure of seed quality and energy reserves $[3,60,61]$, did not. This result supports the observation that seed count in many plant species tends to vary in response to environmental changes, while seed mass remains relatively constant $[60,61]$.

\section{Conclusion}

Clearly, the manner of apical meristem damage had an effect on the plant's compensatory response. Borrichia frutescens appears to be poorly adapted to damage that abruptly removes the apical meristem (e.g., chewing damage), especially when it occurs early in the season. However, even clipped plants, which exhibited more adverse effects than galled ones, largely recovered vegetative growth by the end of the study. Results from this study suggest that $B$. frutescens is better adapted to galling by $A$. borrichiae in terms of regrowth and reproduction compared to chewing damage. Moreover, we suggest possible resource regulation of apical meristems by the gall-inducer.

\section{Conflict of Interests}

The authors declare that there are no conflict of interests regarding the publication of this paper.

\section{Acknowledgments}

The authors thank Dr. D. Moon (University of North Florida) and Dr. J. Smith (University of Florida) for reviewing this paper; M. Masdea, N. Millan, and R. Fuller for assisting with field research; and J. Evans (Sanibel-Captiva Conservation Foundation Native Plant Nursery) for information about Borrichia frutescens seed germination. In addition, we would like 
to thank the anonymous reviewers for their comments, which improved the paper. This work was conducted under National Park Service permit No. TIMU-2013-SCI-0001, study No. TIMU-00014. It was funded in part by a Timucuan Preserve Research Grant awarded by the Timucuan Ecological and Historic Preserve (U.S. NPS) and Timucuan Trail Parks Foundation and a University of North Florida Travel Award from the UNF Biology Department.

\section{References}

[1] D. A. Jameson, "Responses of individual plants to harvesting," The Botanical Review, vol. 29, no. 4, pp. 532-594, 1963.

[2] D. R. Strong, J. H. Lawton, and R. Southwood, Insects on Plants: Community Patterns and Mechanisms, Harvard University Press, Cambridge, Mass, USA, 1984.

[3] K. N. Paige and T. G. Whitham, "Overcompensation in response to mammalian herbivory: the advantage of being eaten," American Naturalist, vol. 129, no. 3, pp. 407-416, 1987.

[4] L. W. Aarssen, "Hypotheses for the evolution of apical dominance in plants: implications for the interpretation of overcompensation," Oikos, vol. 74, no. 1, pp. 149-156, 1995.

[5] R. J. Marquis, "Plant architecture, sectoriality and plant tolerance to herbivores," Vegetatio, vol. 127, no. 1, pp. 85-97, 1996.

[6] A.-P. Huhta, T. Lennartsson, J. Tuomi, P. Rautio, and K. Laine, "Tolerance of Gentianella campestris in relation to damage intensity: an interplay between apical dominance and herbivory," Evolutionary Ecology, vol. 14, no. 4-6, pp. 373-392, 2000.

[7] K. Lehtilä, "Modelling compensatory regrowth with bud dormancy and gradual activation of buds," Evolutionary Ecology, vol. 14, no. 4-6, pp. 315-330, 2000.

[8] K. A. Stowe, R. J. Marquis, C. G. Hochwender, and E. L. Simms, "The evolutionary ecology of tolerance to consumer damage," Annual Review of Ecology and Systematics, vol. 31, pp. 565-595, 2000.

[9] J. Fornoni, J. Núñez-Farfán, and P. L. Valverde, "Evolutionary ecology of tolerance to herbivory: advances and perspectives," Comments on Theoretical Biology, vol. 8, no. 6, pp. 643-663, 2003.

[10] M. J. Wise and W. G. Abrahamson, "Beyond the compensatory continuum: environmental resource levels and plant tolerance of herbivory," Oikos, vol. 109, no. 3, pp. 417-428, 2005.

[11] M. J. Wise and W. G. Abrahamson, "Applying the limiting resource model to plant tolerance of apical meristem damage," American Naturalist, vol. 172, no. 5, pp. 635-647, 2008.

[12] S. Strauss and A. Zangerl, "Plant-insect interactions in terrestrial ecosystems," in Plant-Animal Interactions: An Evolutionary Approach, C. Herrera and O. Pellmyr, Eds., pp. 77-106, WileyBlackwell, Hoboken, NJ, USA, 2009.

[13] P. R. Ehrlich and P. H. Raven, "Butterflies and plants: a study in coevolution," Evolution, vol. 18, no. 4, pp. 586-608, 1964.

[14] A. Kessler and I. T. Baldwin, "Plant responses to insect herbivory: the emerging molecular analysis," Annual Review of Plant Biology, vol. 53, pp. 299-328, 2002.

[15] J. P. Rosenthal and P. M. Kotanen, "Terrestrial plant tolerance to herbivory," Trends in Ecology and Evolution, vol. 9, no. 4, pp. 145-148, 1994.

[16] T. Lennartsson, P. Nilsson, and J. Tuomi, "Induction of overcompensation in the field gentian, Gentianella campestris," Ecology, vol. 79, no. 3, pp. 1061-1072, 1998.
[17] B. L. Benner, "Effects of apex removal and nutrient supplementation on branching and seed production inThlaspi arvense (Brassicaceae)," American Journal of Botany, vol. 75, no. 5, pp. 645-561, 1988.

[18] D. W. Inouye, “The consequences of herbivory: a mixed blessing for Jurinea mollis (Asteraceae)," Oikos, vol. 39, no. 2, pp. 269$272,1982$.

[19] T. G. Whitham, J. Maschinski, K. C. Larson, and K. N. Paige, "Plant responses to herbivory: the continuum from negative to positive and underlying physiological mechanisms," in PlantAnimal Interactions: Evolutionary Ecology in Tropical and Temperate Regions, P. W. Price, T. M. Lewinsohn, G. W. Fernandes, and W. W. Benson, Eds., pp. 227-256, John Wiley \& Sons, New York, NY, USA, 1991.

[20] R. Karban and S. Y. Strauss, "Effects of herbivores on growth and reproduction of their perennial host, Erigeron glaucus," Ecology, vol. 74, no. 1, pp. 39-46, 1993.

[21] P. Olejniczak, "Overcompensation in response to simulated herbivory in the perennial herb Sedum maximum," Plant Ecology, vol. 212, no. 11, pp. 1927-1935, 2011.

[22] A. E. Weis, R. Walton, and C. L. Crego, "Reactive plant tissue sites and the population biology of gall makers," Annual Review of Entomology, vol. 33, pp. 467-486, 1988.

[23] F. Dreger-Jauffret and J. D. Shorthouse, "Diversity of gallinducing insects and their galls," in Biology of Insect-Induced Galls, J. D. Shorthouse and O. Rohfritsch, Eds., pp. 8-33, Oxford University Press, New York, NY, USA, 1992.

[24] M. S. Mani, "Introduction to cecidology," in Biology of InsectInduced Galls, J. D. Shorthouse and O. Rohfritsch, Eds., pp. 3-7, Oxford University Press, New York, NY, USA, 1992.

[25] O. Rohfritsch, "Patterns in gall development," in Biology of Insect-Induced Galls, J. D. Shorthouse and O. Rohfritsch, Eds., pp. 60-86, Oxford University Press, New York, NY, USA, 1992.

[26] A. Raman, C. W. Schaefer, and T. M. Withers, "Galls and gallinducing arthropods: an overview of their biology, ecology, and evolution," in Biology, Ecology, and Evolution of Gall-Inducing Arthropods, A. Raman, C. W. Schaefer, and T. M. Withers, Eds., pp. 1-34, Science Publishers, Enfield, NH, USA, 2005.

[27] J. Yukawa and O. Rohfritsch, "Biology and ecology of gallinducing Cecidomyiidae (Diptera)," in Biology, Ecology, and Evolution of Gall-Inducing Arthropods, A. Raman, C. W. Schaefer, and T. M. Withers, Eds., pp. 273-304, Science Publishers, Enfield, NH, USA, 2005.

[28] R. J. Gagné, The Plant-Feeding Gall Midges of North America, Cornell University Press, Ithaca, NY, USA, 1989.

[29] A. M. Rossi, "Speciation processes among insects," in Encyclopedia of Entomology, J. L. Capinera, Ed., pp. 2060-2062, Kluwer Academic Publishers, London, UK, 2004.

[30] M. A. A. Carneiro, C. S. A. Branco, C. E. D. Braga et al., "Are gall midge species (Diptera, Cecidomyiidae) host-plant specialists?" Revista Brasileira de Entomologia, vol. 53, no. 3, pp. 365-378, 2009.

[31] T. P. Craig, P. W. Price, and J. K. Itami, "Resource regulation by a stem-galling sawfly on the arroyo willow," Ecology, vol. 67, no. 2, pp. 419-425, 1986.

[32] H. Roininen, P. W. Price, and J. Tahvanainen, "Field test of resource regulation by the bud-galling sawfly, Euura mucronata, on Salix cinerea," Holarctic Ecology, vol. 11, no. 2, pp. 136-139, 1988.

[33] A. M. Rossi and D. R. Strong, "A new species of Asphondylia (Diptera: Cecidomyiidae) on Borrichia (Asteraceae) 
from Florida," Proceedings of the Entomological Society of Washington, vol. 92, no. 4, pp. 732-735, 1990.

[34] M. M. Espírito-Santo, F. D. S. Neves, F. R. Andrade-Neto, and G. W. Fernandes, "Plant architecture and meristem dynamics as the mechanisms determining the diversity of gall-inducing insects," Oecologia, vol. 153, no. 2, pp. 353-364, 2007.

[35] J. M. Carlton, A Guide to Common Florida Salt Marsh and Mangrove Vegetation, Florida Department of Natural Resources, Florida Marsh Research Publications, St. Petersburg, Fla, USA, 1975.

[36] A. Cronquist, Vascular Flora of the Southeastern United States: Vol. 1, Asteraceae, University of North Carolina Press, Chapel Hill, NC, USA, 1980.

[37] A. E. Antlfinger, "The genetic basis of microdifferentiation in natural and experimental populations of Borrichia frutescens in relation to salinity," Evolution, vol. 35, no. 6, pp. 1056-1068, 1981.

[38] W. H. Duncan and M. B. Duncan, Seaside Plants of the Gulf and Atlantic States, Smithsonian Institution Press, Washington, DC, USA, 1987.

[39] P. Biber, J. D. Caldwell, S. R. Caldwell, and M. Marenberg, SeaOxeye Daisy, Borrichia Frutescens, Propagation Guide, Center for Plant Restoration and Coastal Plant Research, University of Southern Mississippi, Ocean Springs, Miss, USA, 2013.

[40] A. M. Rossi, P. D. Stiling, D. R. Strong, and D. M. Johnson, “Does gall diameter affect the parasitism rate of Asphondylia borrichiae (Diptera: Cecidomyiidae)?" Ecological Entomology, vol. 17, no. 2, pp. 149-154, 1992.

[41] A. M. Rossi and P. D. Stiling, "Intraspecific variation in growth rate, size, and parasitism of galls induced by Asphondylia borrichiae (Diptera: Cecidomyiidae) on three host species," Annals of the Entomological Society of America, vol. 88, no. 1, pp. 39-44, 1995.

[42] A. M. Rossi, P. Stiling, M. V. Cattell, and T. I. Bowdish, "Evidence for host-associated races in a gall-forming midge: trade-offs in potential fecundity," Ecological Entomology, vol. 24, no. 1, pp. 95-102, 1999.

[43] K. Stokes, P. Stiling, M. Gilg, and A. M. Rossi, “The gall midge Asphondylia borrichiae Rossi \& Strong (Diptera: Cecidomyiidae): an indigenous example of host-associated sympatric genetic divergence," Environmental Entomology, vol. 41, no. 5, pp. 1246-1254, 2012.

[44] J. C. Roskam, "Evolution of the gall-inducing guild," in Biology of Insect-Induced Galls, J. D. Shorthouse and O. Rohfritsch, Eds., pp. 34-49, Oxford University Press, New York, NY, USA, 1992.

[45] P. Stiling, A. M. Rossi, D. R. Strong, and D. M. Johnson, "Life history and parasites of Asphondylia borrichiae (Diptera: Cecidomyiidae), a gall maker on Borrichia frutescens," Florida Entomologist, vol. 75, no. 1, pp. 130-137, 1992.

[46] J. Yukawa, "Synchronization of gallers with host plant phenology," Population Ecology, vol. 42, no. 2, pp. 105-113, 2000.

[47] A. M. Rossi, M. Murray, K. Hughes, M. Kotowski, D. C. Moon, and P. Stiling, "Non-random distribution among a guild of parasitoids: implications for community structure and host survival," Ecological Entomology, vol. 31, no. 6, pp. 557-563, 2006.

[48] D. Te Strake, A. H. Keagy, and P. D. Stiling, "Fungi associated with Borrichia frutescens (Asteraceae): insect galls and endophytes," SIDA, Contributions to Botany, vol. 22, no. 1, pp. 755$763,2006$.

[49] P. Stiling and A. M. Rossi, "Coastal insect herbivore communities are affected more by local environmental conditions than by plant genotype," Ecological Entomology, vol. 20, no. 2, pp. 184190, 1995.

[50] P. Stiling, A. M. Rossi, M. Cattell, and T. I. Bowdish, "Weak competition between coastal insect herbivores," Florida Entomologist, vol. 82, no. 4, pp. 599-608, 1999.

[51] D. C. Moon and P. Stiling, "The influence of species identity and herbivore feeding mode on top-down and bottom-up effects in a salt marsh system," Oecologia, vol. 133, no. 2, pp. 243-253, 2002.

[52] E. Van Der Meijden, "Herbivory as a trigger for growth," Functional Ecology, vol. 4, no. 4, pp. 597-598, 1990.

[53] K. A. Franklin, "Shade avoidance," New Phytologist, vol. 179, no. 4, pp. 930-944, 2008.

[54] M. A. Domagalska and O. Leyser, "Signal integration in the control of shoot branching," Nature Reviews Molecular Cell Biology, vol. 12, no. 4, pp. 211-221, 2011.

[55] M. G. Cline, "Apical dominance," The Botanical Review, vol. 57, no. 4, pp. 318-358, 1991.

[56] H. Smith and G. C. Whitelam, "The shade avoidance syndrome: multiple responses mediated by multiple phytochromes," Plant, Cell and Environment, vol. 20, no. 6, pp. 840-844, 1997.

[57] G. W. Fernandes and S. P. Ribeiro, "Plant response to herbivory: two examples from the neotropics," Ecotropicos, vol. 3, no. 2, pp. 77-86, 1990.

[58] A. G. Stephenson, "Flower and fruit abortion: proximate causes and ultimate functions," Annual Review of Ecology and Systematics, vol. 12, pp. 253-279, 1981.

[59] O. Rohfritsch, "Plants, gall midges, and fungi: a threecomponent system," Entomologia Experimentalis et Applicata, vol. 128, no. 1, pp. 208-216, 2008.

[60] J. L. Harper, Population Biology of Plants, Academic Press, London, UK, 1977.

[61] B. A. Schaal, "Reproductive capacity and seed size in Lupinus texensis," American Journal of Botany, vol. 67, no. 5, pp. 703-709, 1980. 

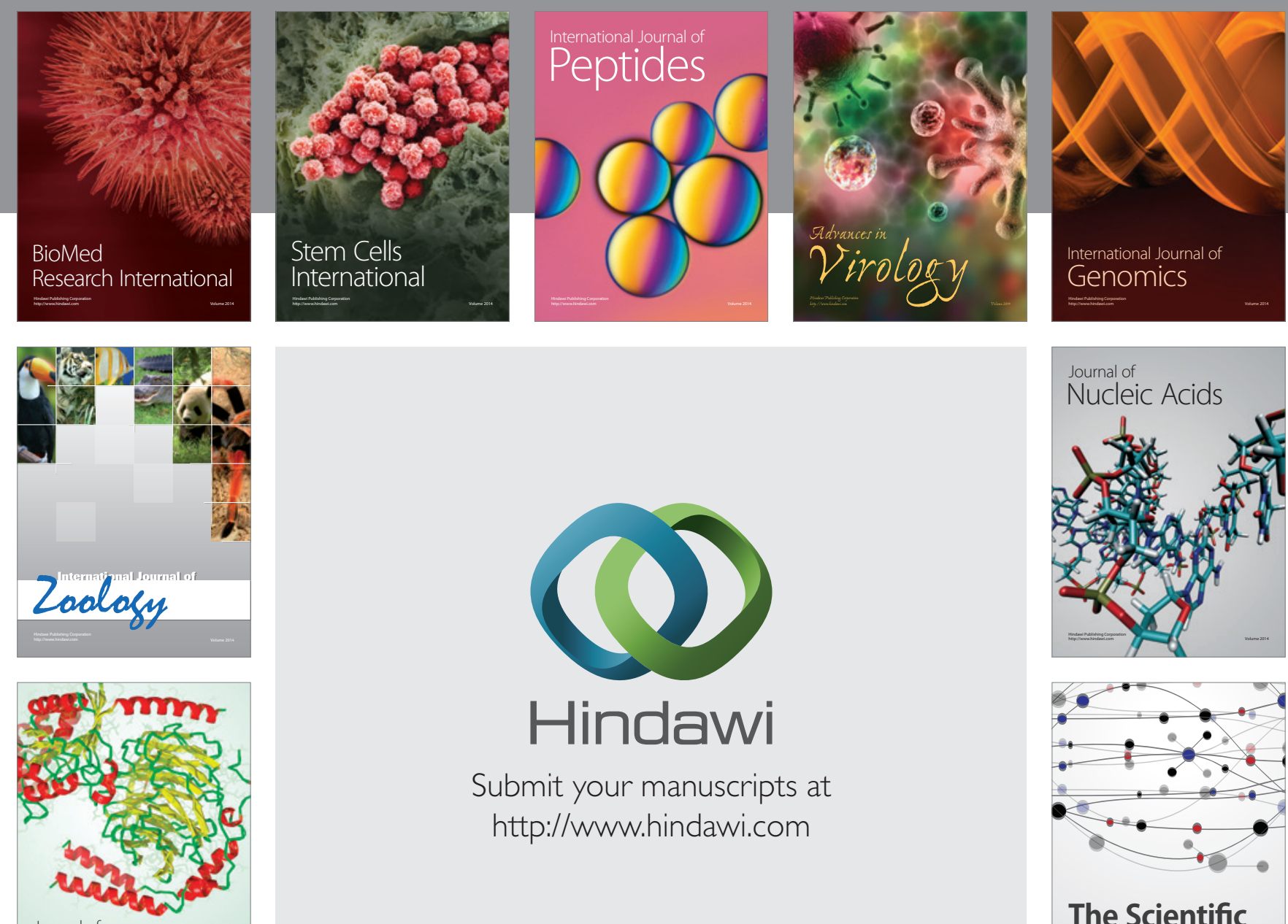

Submit your manuscripts at

http://www.hindawi.com

Journal of
Signal Transduction
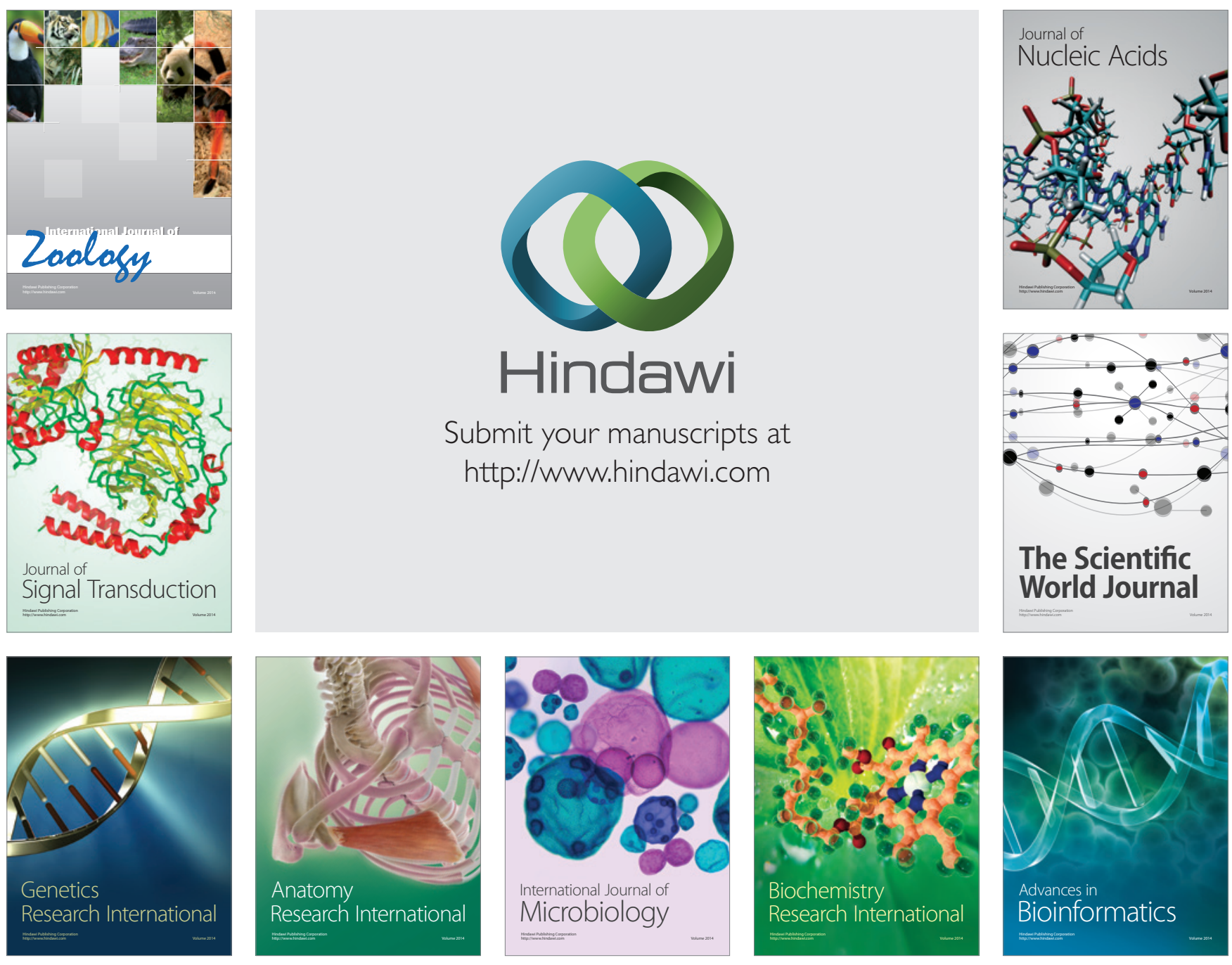

The Scientific World Journal
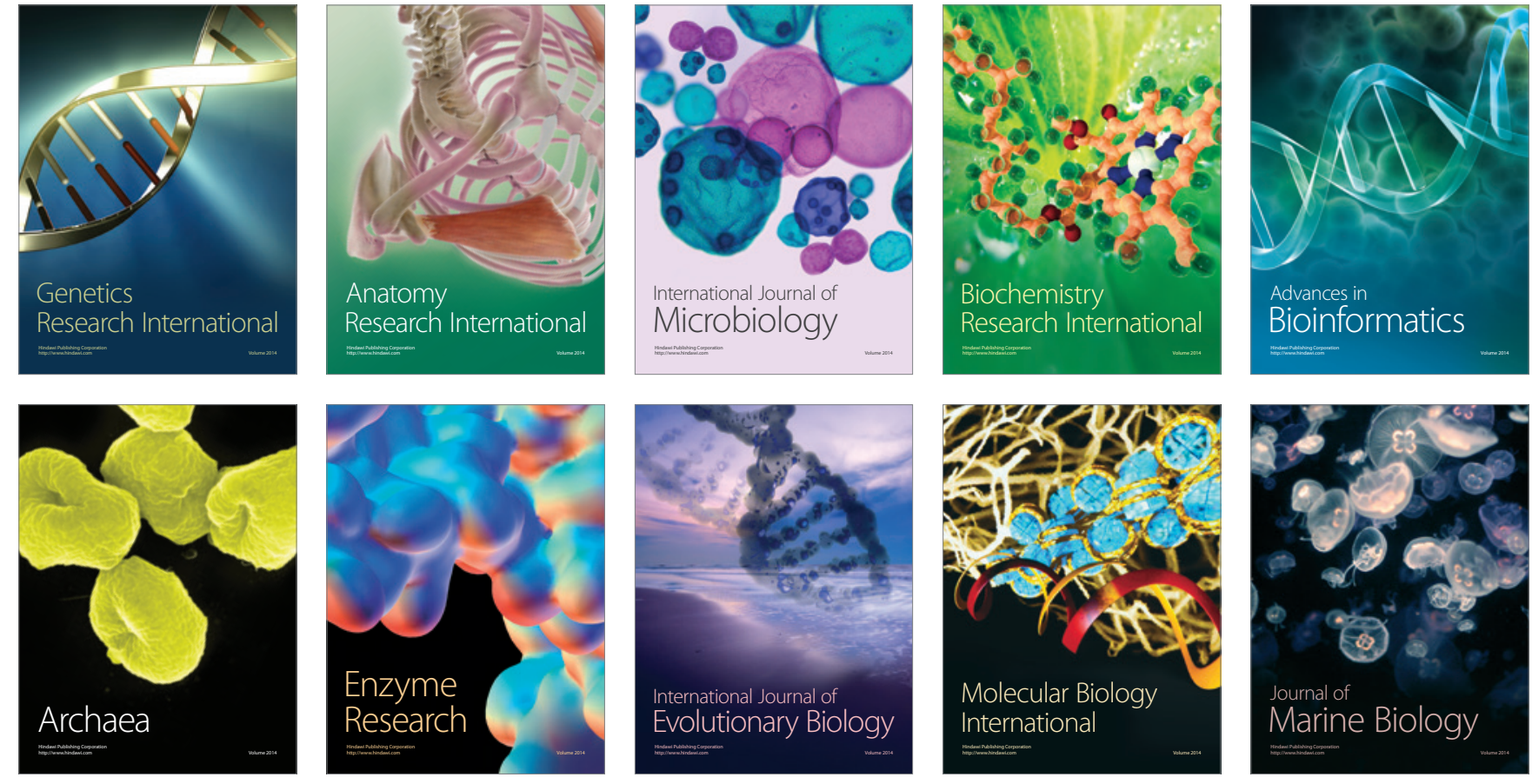